\title{
Liquid organic fertilizer production for growing vegetables under hydroponic condition
}

\author{
Thanaporn Phibunwatthanawong ${ }^{1} \cdot$ Nuntavun Riddech $^{2,3}$
}

Received: 5 June 2018 / Accepted: 16 March 2019 / Published online: 25 March 2019

(c) The Author(s) 2019

\begin{abstract}
Purpose Liquid organic fertilizers produced from agricultural residues and industrial wastes are becoming increasingly popular. This study aimed to examine the effect of liquid organic fertilizers produced from waste molasses, distillery slop and sugarcane leaves on the growth of Green Cos Lettuce (Lactuca sativa var. longifolia).

Methods Six formulas of liquid organic fertilizers were produced with different ratios of substrates (molasses, distillery slop and sugarcane leaves). The measurements of chemical, microbiological and germination index of fertilizers were studied. Hydroponic using nutrient film technique system was used to grow vegetables with fertilizers.

Results Fertilizers showed the ranges of chemical parameters as follows: $\mathrm{pH} 4.5-7.8$, EC $25-33 \mathrm{dS} / \mathrm{m}$, total N $0.14-0.33 \%$, total $\mathrm{P}_{2} \mathrm{O}_{5} 0.002-0.017 \%$, total $\mathrm{K}_{2} \mathrm{O} 0.81-11.8 \%$, OM 0.26-3.25\%, OC 0.26-3.20\% and C:N ratio 6.14-17.92. Microbiological analysis indicated total microorganism of 9.99-9.05 $\log$ CFU/ml. Nitrogen fixers, phosphate and potassium solubilizing agents were found in all formulas. IAA concentration was $1.13-59.53 \mathrm{mg} / \mathrm{l}$. The fertilizers produced after 30 days of fermentation and used at a dilution of 1:100 gave more than 100\% germination index showing non-phytotoxicity characteristics. The results for the hydroponic system showed that liquid fertilizer formula 3 (distillery slop: sugarcane leaves: filtrate water 1:0.1:0.25 v:w:v) and formula 5 (distillery slop: sugarcane leaves 1:0.25:0.25 v:w:v) demonstrated the best growth performance, which was similar to plants treated with liquid chemical fertilizer.

Conclusion This study showed that organic liquid fertilizers formulas 3 and 5 had similar growth promotion properties as chemical fertilizers with Green Cos Lettuce. Moreover, our products are organic and serve as a rich nutrient source for the plant.
\end{abstract}

Keywords Bio-based $\cdot$ Green Cos Lettuce $\cdot$ Sustainable $\cdot$ Agricultural residues $\cdot$ Waste

\section{Introduction}

In Thailand, liquid organic fertilizers produced from agricultural residues and industrial wastes are becoming increasingly popular. These fertilizers are produced by simple fermentation processes using organic wastes as carbon substrates. Liquid organic fertilizers consist of essential plant

Nuntavun Riddech

nunrid@kku.ac.th

1 Graduation School of Science, Department of Microbiology, Faculty of Science, Khon Kaen University, Khon Kaen 40002, Thailand

2 Department of Microbiology, Faculty of Science, Khon Kaen University, Khon Kaen 40002, Thailand

3 Salt-tolerant Rice Research Group, Faculty of Science, Khon Kaen University, Khon Kaen 40002, Thailand nutrients and beneficial microorganisms, which recycle organic matter. Microorganisms have an important role on the degradation of substrates in the fermentation process. At the end of the fermentation process, phytohormones such as auxin and cytokinin, organic acids and plant growth promoters are present in the liquid organic fertilizers. Molasses and distillery slop are carbon rich wastes from agro-industry factories. Molasses is a dark-colored, sweet and syrupy byproduct of sugar extraction from sugarcane and sugar beets and contains concentrated levels of vitamins and minerals. It is an important carbon source for microbial growth. Distillery slop, which contains high levels of organic pollutants, is a waste product of the distilling process at ethanol factories. It is usually costly to treat wastewater contaminated with distillery slop. However, it is a rich source of nutrients (nitrogen, phosphorus and potassium). Sugarcane leaves, which provide a source of organic matter, are a waste product of 
sugarcane harvesting. In Thailand, the leaves are usually burnt (Sangla and Suppadit, 2005) to facilitate the harvest. This practice causes serious air pollution and destroys organisms and microbes on the surface of the soil. All the organic residues mentioned above have the potential to be used as substrates for liquid organic fertilizer production.

Hydroponics is the soil-less cultivation of plants using mineral nutrient solutions (Sardare and Admane 2013). In this method, nutrients are fed directly to the roots. It is a highly precise and demanding method that requires a greater amount of production knowledge, experience, technical skill, and financial investment than many other greenhouse systems. There are many advantages of growing plants under soil-less culture over soil-based culture (Savvas 2002). Five types of hydroponics systems are recognized including NFT (Nutrient Film Technique), NFLT (Nutrient Flow Technique), DFT (Deep Flow Technique), DRFT (Dynamic Root Floating Technique) and FAD (Food and Drain). Hydroponic lettuce is commonly produced using either the nutrient film technique (NFT) or the floating raft method, both as closed systems. This means less water is used when compared to ground cultivation. While hydroponics is an excellent technique for the cultivation of vegetable crops and other plants, organic fertilizers cannot be used in conventional hydroponic systems, which generally utilize only inorganic fertilizers. These chemical fertilizers are a major constituent in hydroponics, but using high concentrations of chemical fertilizer may pose a risk to consumers due to the accumulation of toxic chemicals in vegetables. $\mathrm{NH}_{4}{ }^{+}$and $\mathrm{NO}_{3}{ }^{-}$are beneficial nutrients for plant growth, yet when chemical fertilizers are used, long-term nitrate accumulation occurs. Nitrates are a naturally occurring form of nitrogen and an integral part of the nitrogen cycle in the environment. As a result of fertilizer use, nitrates tend to accumulate in vegetable leaves, and this is true of lettuce (Gent 2003). High levels of nitrate accumulation in plants are harmful to both human health and to plant growth (Anjana and Iqbal 2007; Ikemoto et al. 2002; Ishiwata et al. 2002). Therefore, the use of liquid organic fertilizer as a replacement or supplement to chemical fertilizer is an attractive solution for hydroponic planting. Moreover, according to Hadad and Anderson (2004), many farmers have an interest in using organic fertilizers for vegetable transplant production. Organic fertilizers are generally insoluble in water, and nutrients are available slowly as they are converted to soluble from by microorganisms. Because the abundance of macro- and micronutrients for plant growth is in liquid organic fertilizer, it has been widely applied to hydroponic plants. Plants can efficiently absorb components dissolved in the liquid fertilizer as growth nutrients. In a previous study, Nasir et al. (2012) used the waste product bio-slurry as a nutrient source for growing hydroponic plants. Bio-slurry is the byproduct of an anaerobic fermentation of organic matter released from biogas reactors after completing methane production. The aim of this study was to use agricultural residues and wastes from factories to produce liquid organic fertilizer and to evaluate the effectiveness of the fertilizer on the promotion of plant growth in a hydroponic system.

\section{Materials and methods}

\section{Liquid organic fertilizer preparation}

Organic substrates used for the production of liquid organic fertilizer included molasses, distillery slop and sugarcane leaves collected from agro-industry factories. Fresh sugarcane leaves were cut into $2 \mathrm{~cm}$ pieces. Molasses was obtained from a sugar factory, and distillery slop from an ethanol factory. The raw materials were analyzed for $\mathrm{pH}$, electrical conductivity, total $\mathrm{N}$, total $\mathrm{P}$ and total $\mathrm{K}$, organic matter; organic carbon, $\mathrm{C} / \mathrm{N}$ ratio and Escherichia coli were detected in molasses and distillery slop.

\section{Liquid organic fertilizer production}

The liquid organic fertilizer was produced using distillery slop, molasses, and sugarcane leaves as substrates. The six formulas of liquid organic fertilizer were produced with different ratio of substrates as follows $\mathrm{F} 1$ (distillery slop:filtrate water 1:0.25 v:v), F2 (distillery slop:molasses:filtrate water 1:0.1:0.25 v:v), F3 (distillery slop:sugarcane leaves:filtrate water 1:0.1:0.25 v:w:v), F4 (distillery slop:sugarcane leaves:molasses:filtrate water 1:0.1:0.1:0.25 v:w:v:v), F5 (distillery slop:sugarcane leaves:filtrate water 1:0.25:0.25 v:w:v) and F6 (distillery slop:sugarcane leaves:molasses:filtrate water 1:0.25:0.1:0.25 $\mathrm{v}: \mathrm{w}: \mathrm{v}: \mathrm{v})$, respectively. The mixture was contained in plastic cans and incubated at ambient temperature for 30 days. The mixture was stirred every 7 days during fermentation process. Liquid organic fertilizer was sampled at day 0,15 and 30 for chemical and microbiological analysis.

\section{Chemical and microbiological parameters measurement in liquid organic fertilizer}

For the chemical parameters such as $\mathrm{pH}$ and electrical conductivity in liquid organic fertilizer were measured by using a pH meter (OHAUS, starter 2100) and EC meter (METTLER TOLEDO, FiveEasy FE30-1), respectively. Total nitrogen was determined using Kjeldahl method (Kjeldahl 1883). Total phosphorus was analyzed by wet digestion spectrophotometer method at the wavelength of $420 \mathrm{~nm}$ (Barton 1948). Analysis of total potassium was performed using Flame photometer (Hesse and Hesse 1971). Organic 
matter and organic carbon were determined using wet oxidation (Black 1965).

For microbiological parameters, samples of liquid organic fertilizers were taken to measure Nitrogen fixation using Ashby's nitrogen free medium (Atlas 2004), Phosphate dissolution was determined using Pikovskaya medium (Surange et al. 1997) with added tricalcium phosphate, and potassium dissolution was determined using Aleksandrov medium $(\mathrm{Hu}$ et al. 2006) with the addition of potassium aluminum silicate. Total microorganism was evaluated by plate count agar (PCA) and E. coli was screened on MacConkey agar.

\section{Indole acetic acid (IAA)}

The IAA content in the liquid organic fertilizer was measured using a modified method of Sarwar et al. (1992). L-trytophan was used as a precursor in the auxin production assay which was composed of $3 \mathrm{ml}$ of liquid organic fertilizer, $6 \mathrm{ml}$ of phosphate buffer $(0.2 \mathrm{M}, \mathrm{pH} 7.0)$ and $4 \mathrm{ml}$ of a

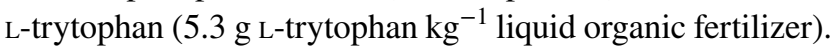
The mixture was incubated on a shaker set at $150 \mathrm{rpm}$ at $35{ }^{\circ} \mathrm{C}$ before being treated with $2 \mathrm{ml}$ of $5 \%$ trichloroacetic acid and $1 \mathrm{ml}$ of calcium chloride $(0.5 \mathrm{M})$ and then filtered through Whatman filter paper No.2. The filtrate $(3 \mathrm{ml})$ was collected and transferred with a tube containing $2 \mathrm{ml}$ of the Salkowski reagent and allowed to stand in darkness for $30 \mathrm{~min}$. The absorbance of the mixture was then determined by measuring absorbance at $535 \mathrm{~nm}$ and the IAA content was determined from an IAA standard curve.

\section{Germination index}

In this study, the vegetable seed was grown in liquid organic fertilizer diluted with distilled water to various concentrations (non-dilution, dilution 1:10 and dilution 1:100). Green Cos Lettuce seed (Lactuca sativa var. longifolla) was used for this test. The seed was dipped in sponge and transferred to float in the liquid organic fertilizer. Seed germination was counted after 5 days of cultivation. Finally, the germination index was calculated following the method of Zucconi et al. (1981).

\section{Growth of Green Cos Lettuce in hydroponics cultivation}

The experiment was conducted between June 2015 and January 2016, in a greenhouse with 45 blocks at KSL Green Innovation Public Company Limited (Khon Kaen, Thailand) factory, Khon Kaen, Thailand. Cultivation was performed in an NFT hydroponic system. Green Cos Lettuce (L. sativa var. longifolla) was chosen as a representative vegetable for this study. Seeds of green Cos-Tiberius RZ for hydroponic cultivation (Rijk zwaan distribution B.V, the Netherlands) were obtained from a local supplier. The experimental design was a completely randomized block with 7 treatments and five replications. The following seven treatments were performed on Green Cos Lettuce:

T1-liquid chemical fertilizer A and B.

T2-liquid organic fertilizer F1.

T3-liquid organic fertilizer F2.

T4-liquid organic fertilizer F3.

T5-liquid organic fertilizer F4.

T6-liquid organic fertilizer F5.

T7-liquid organic fertilizer F6.

Before use, liquid organic fertilizer was diluted with dechlorinated tap water in the ratio 1:100 $(\mathrm{v} / \mathrm{v})$. The proportion of liquid chemical fertilizer A and B (hydrowork, http:// www.higreenfarm.com) per tap water was 1:1:200 (v/v). All nutrients solutions were adjusted to $\mathrm{pH} 4-5$ and EC $2-3 \mathrm{dS} / \mathrm{m}$ by dilution with tap water. The seeds were placed in a seed sponge and moistened with water for 10 days. After 10 days, the seedlings were transplanted into the hydroponic system containing nutrients (T1-T7). The nutrients were automatically fed by a closed-loop system. Fertilizers were applied every week until harvesting at 28 days after transplanting (DAT). The hydroponic system was placed in a greenhouse lined with blue net to protect from direct sunlight. The effects of each treatment on the growth of Green Cos Lettuce were recorded by measuring plant growth parameters as follows: shoot fresh and dry weight, length of leaf, number of leaves, root length biomass and chlorophylls content (Arnon 1949).

\section{Statistical analysis}

Analysis of variance (ANOVA) was performed using STATISTIX 10. Significance of means was analyzed with least significant differences (LSD) between treatments means at $P<0.05$ and $P<0.01$.

\section{Results and discussion}

\section{Liquid organic fertilizer production}

$\mathrm{pH}, \mathrm{EC}$, total $\mathrm{N}$, total $\mathrm{P}$ and total $\mathrm{K}$, organic matter organic carbon, $\mathrm{C} / \mathrm{N}$ ratio and $E$. coli in the original substrates (e.g., molasses, distillery slop and sugarcane leaves) were measured and the results of chemical properties of the original substrates are shown in Table 1. The average EC values of molasses and distillery slop were 39.10 and $32.86 \mathrm{dS} / \mathrm{m}$, respectively. These values are extremely high, indicating a large salt content. 
Table 1 Chemical characteristics of the original substrates (molasses, distillery slop and sugarcane leaves)

\begin{tabular}{lccl}
\hline Characteristic & \multicolumn{2}{l}{ Kind of substrates } & \\
\cline { 2 - 4 } & Molasses & Distillery slop & Sugarcane leaves \\
\hline $\mathrm{pH}$ & 6.69 & 7.14 & $\mathrm{Nd}$ \\
Electrical conductivity (dS/m) & 39.10 & 32.86 & $\mathrm{Nd}$ \\
Total N (\%) & 0.92 & 0.15 & 1.12 \\
Total P (\%) & 0.04 & 0.08 & 0.08 \\
Total K (\%) & 5.25 & 1.1 & 2.45 \\
Organic matter $(\%)$ & 75.47 & 3.39 & 88.0 \\
Organic carbon $(\%)$ & 43.77 & 1.97 & 51.04 \\
E. coli & 0.00 & 0.00 & nd \\
\hline
\end{tabular}

The values shown in this table were the mean $n d$ not determined
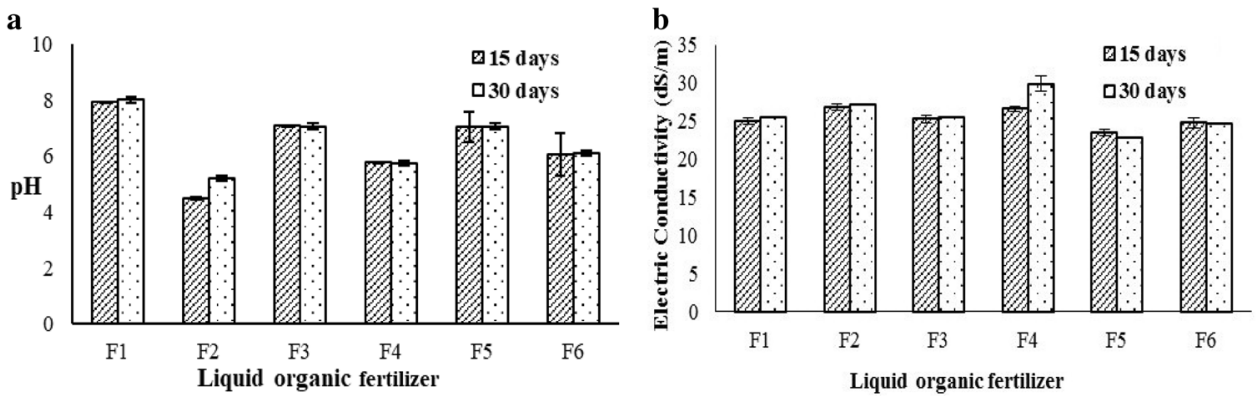

Fig. $1 \mathrm{pH}(\mathbf{a})$ and $\mathrm{EC}(\mathbf{b})$ of liquid organic fertilizers (F1-F6 were liquid organic fertilizer formula 1-6) (all values were mean $n=3$ and SE bars were showed)
The $\mathrm{pH}$ (Fig. 1a) of liquid organic fertilizer formulas 1 (F1), 3 (F3) and 5 (F5) proved most suitable, whereas those of F2, F4 and F6 were slightly acidic. These results were similar to those of Saelee (2004), who found that most liquid organic fertilizers suitable for agricultural production had $\mathrm{pH}$ in the range 3-5. These acidic $\mathrm{pH}$ values were due to the amount of sugars in the substrate which are converted to lactic acid or acetic acid by the activities of microorganisms. All formulas had very high values of EC (Fig. 1b) due to the high levels in the natural substrate such as molasses and distillery slop. Good quality liquid organic fertilizers should normally have a $\mathrm{pH}$ less than 5 and an EC value less than $20 \mathrm{dS} / \mathrm{m}$. Such values are the standards for liquid organic fertilizer in Thailand (National Bureau of Agricultural Commodity and Food Standards, Ministry of Agriculture and Cooperatives 2005). The values reported here were consistent with those recorded by Saouy (2002), who showed that some liquid organic fertilizers had high electrical conductivity $(0.03-93.1 \mathrm{dS} / \mathrm{m})$. The results of the chemical analysis of liquid organic fertilizer after periods of fermentation are presented in Table 2. After 15 days of fermentation, liquid organic fertilizer formula 4 (F4) had the highest content of total N $(0.21 \%)$, total P $(0.015 \%)$, total K $(1.08 \%)$, OM $(5.89 \%)$, OC $(3.43 \%)$ and $\mathrm{C} / \mathrm{N}$ ratio (16.41). After 30 days of fermentation, the highest total $\mathrm{N}(0.33 \%)$ and total $\mathrm{K}(1.18 \%)$ were found in F6. In contrast, F3 had very high of C/N ratio (17.92) compared to all other formula. Total $\mathrm{N}$ content increased with time of fermentation due to the activity of nitrogen-fixing microorganisms. The microorganism decomposed organic nitrogen materials in the fermentation process (Moonrat 2010). The results showed that the dissolution of phosphate was high due to the large population of phosphate dissolving microorganisms which had an important role in mineralizing P (Sureshkumar et al. 2013). The total $\mathrm{K}$ content, however, mostly remained stable. Liquid organic fertilizer had low nutrient content due to decomposition by microorganisms converting the substrates to nutrient content. The total amounts of $\mathrm{N}$ and $\mathrm{P}$ were lower than those present in the liquid organic fertilizer standard of Thailand, which are greater than $0.5 \%$. However, total $\mathrm{K}$ showed higher value than the standard $(0.5 \%)$ as the substrates used in this study contained large amounts of phosphorus. The organic carbon content decreased when the fermentation process was complete. During microbial fermentation, microorganisms used organic carbon as a source of energy and nutrients (Yusran 2008). Organic carbon was converted to carbon dioxide, resulting in reduced carbon content due to loss of atmosphere (Alexander 1977). Measuring $\mathrm{C} / \mathrm{N}$ ratio in liquid organic fertilizer during fermentation found that the $\mathrm{C} / \mathrm{N}$ ratio at 30 days of fermentation showed the $\mathrm{C} / \mathrm{N}$ ratio value was lower than 20. According to the report Leblanc et al. (2007), if the $\mathrm{C} / \mathrm{N}$ ratio of a fertilizer was lower than 20 , the substrate 


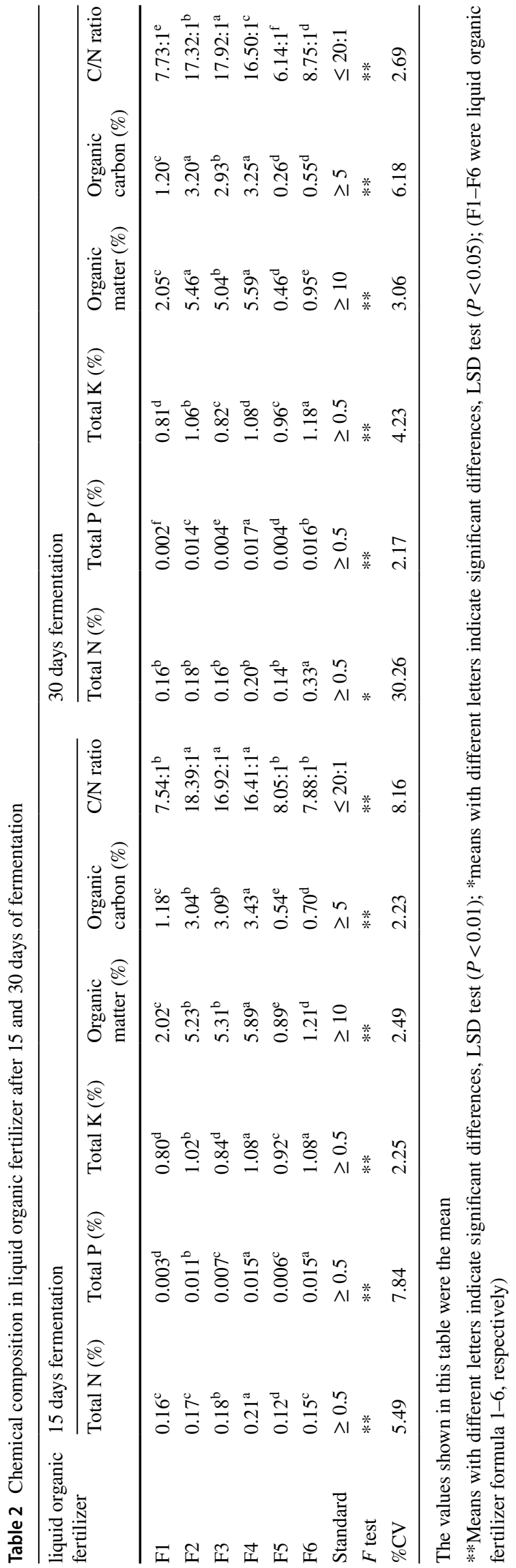

was easily degraded, initially immobilized by microbes. In addition, the $\mathrm{C} / \mathrm{N}$ ratio is an important requirement for microorganisms, which use carbon as an energy source and nitrogen as a basic element for the formation of protein and other constituents of the cell protoplasm and microbial and organic carbon. This activates microbial cellulolytic and microbial proliferation which immobilize N (Satisha and Devarajan 2007).

A nutrient solution is used in normal hydroponic cultivation for plant nurseries and commercial greenhouses. This commercial nutrient solution consists of two concentrated solutions, namely "solution A" and "solution B", which is typical of any hydroponic recipe (Jones 2016). The chemical composition of the liquid chemical fertilizer ( $\mathrm{A}$ and $\mathrm{B}$ ) used in this study has the $\mathrm{pH}$ : 6.20-6.41, EC: 3.01-3.25 dS/m, Total N (0.139-0.198\%), P (0.005-0.310\%), K (0.002-2.530\%) (Table 3). This shows that the nitrogen, phosphorus and potassium content in chemical fertilizer was higher than in the liquid organic fertilizer product. Furthermore, nitrate levels were also higher in chemical fertilizers $(32,240 \mathrm{mg} / \mathrm{l})$. These nitrates accumulate in the plant and consequently can be harmful to both human health and plant growth (Ikemoto et al. 2002; Ishiwata et al. 2002; Anjana and Iqbal 2007).

\section{Change of microbial population in liquid organic fertilizer during fermentation}

Molasses or sugar was used as raw materials for the fermentation of liquid organic fertilizer utilizing the plasmolysis process. The plant cell was autolysis in this condition and released organic matter such as amino acids, and carbohydrates inside the cell. These substances were degraded by microorganisms with natural contaminates in the substrate, producing amino acids, hormones, and enzymes (Wiparwin 2006).

The process of producing organic fertilizer was directly related to microbial decomposition of the substrate. The population of plant growth-promoting microorganisms in liquid organic fertilizer was determined for all formulations. The results showed that plant growth-promoting bacteria (such as nitrogen fixer bacteria) were present in the system and led to an increase in biomass yield. Phosphate solubilizing bacteria and potassium solubilizing bacteria were also present in the fertilizer. Plant growthpromoting bacteria assist plant growth, and the inclusion of such bacteria in liquid organic fertilizer could increase organic N and nutrient content. Ratneetoo (2012) reported that microbes were beneficial to plant growth, helping to circulate nutrients to plants. F6 has the highest in total bacteria in the sample as compared to other liquid organic fertilizers $(P<0.05)$ (Fig. 2). The beneficial microbes in 
Table 3 Chemical composition of liquid chemical fertilizers A and B used in this study

\begin{tabular}{|c|c|c|c|c|c|c|c|c|}
\hline $\begin{array}{l}\text { Liquid chemical } \\
\text { fertilizer }\end{array}$ & $\mathrm{pH}$ & $\mathrm{EC}(\mathrm{dS} / \mathrm{m})$ & Total N (\%) & Total P (\%) & Total K (\%) & $\begin{array}{l}\text { Organic mat- } \\
\text { ter }(\%)\end{array}$ & $\begin{array}{l}\text { Organic } \\
\text { carbon }(\%)\end{array}$ & $\mathrm{NO}_{3}{ }^{-}(\mathrm{mg} / \mathrm{l})$ \\
\hline A & 6.41 & 3.01 & 0.139 & 0.005 & 0.002 & 0.277 & 0.160 & 32,240 \\
\hline B & 6.20 & 3.25 & 0.198 & 0.310 & 2.530 & 0.132 & 0.076 & 27,115 \\
\hline
\end{tabular}

Fig. 2 Microbiological analysis of six formulas of liquid organic fertilizer after 30 days of fermentation. Different letters indicate significant difference values at $P<0.05$ by LSD (all values were mean $n=3$ and SE bars were shown) (F1-F6 were liquid organic fertilizer formula 1-6)

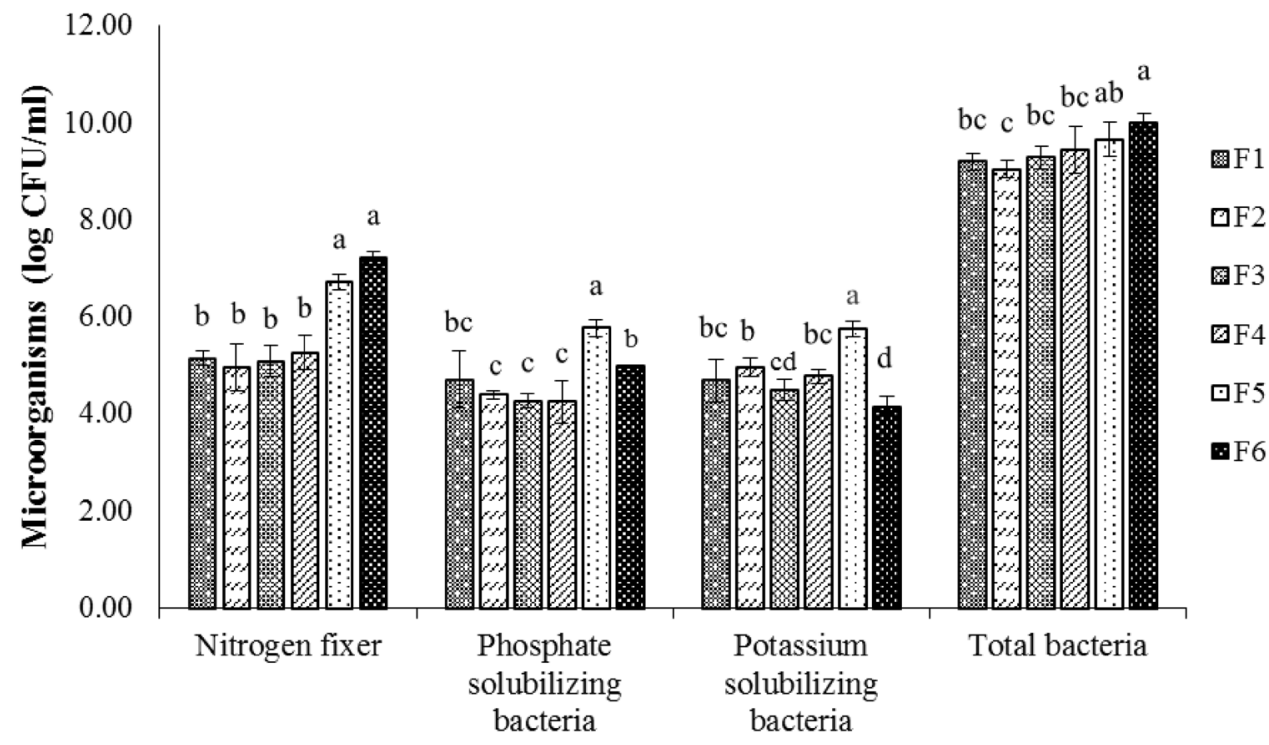

the fertilizer could improve product quality, through the application of a sustainable fermentation process. All fertilizer standards were tested for human pathogen contamination and importantly E. coli was not found in any of the liquid organic fertilizers.

\section{Indole acetic acid (IAA)}

Pizzeghello et al. (2001) and Glick (2003) explained that plant growth hormones are produced within the plant through synthesis of the microorganism in the fertilizer. At the end of the fermentation process, microorganisms play an important role producing phytohormones such as auxin and cytokinin, organic acids and plant growth promoters which appear in liquid organic fertilizers. Therefore, the plant growth-promoting activity of microorganisms can be related to the production of auxins (Ortíz-Castro et al. 2009). The microbial population produces auxins as part of their metabolism including indole-3-acetic acid (IAA) (Patten and Glick 1996). According to Lwin et al. 2012, IAA hormone was detected in $80 \%$ of bacteria isolated from the rhizosphere. Consequently, IAA production was a determinant trait both for plant growth-promoting rhizobacteria (PGPR) (Patten and Glick 1996, 2002). The assay of indole acetic acid (IAA) in liquid organic fertilizers
Table 4 Indole acetic acid in different formulas of liquid organic fertilizer

\begin{tabular}{lll}
\hline $\begin{array}{l}\text { Liquid organic } \\
\text { fertilizer }\end{array}$ & \multicolumn{1}{l}{ IAA $(\mathrm{mg} / \mathrm{l})$} \\
\cline { 2 - 3 } & 15 days fermentation & 30 days fermentation \\
\hline F1 & $4.27 \pm 1.42^{\mathrm{b}}$ & $8.08 \pm 0.16^{\mathrm{d}}$ \\
F2 & $11.68 \pm 0.09^{\mathrm{a}}$ & $34.75 \pm 0.91^{\mathrm{b}}$ \\
F3 & $7.12 \pm 0.46^{\mathrm{b}}$ & $9.28 \pm 0.15^{\mathrm{c}}$ \\
F4 & $5.42 \pm 4.00^{\mathrm{b}}$ & $4.51 \pm 0.22^{\mathrm{e}}$ \\
F5 & $0.90 \pm 0.32^{\mathrm{c}}$ & $1.13 \pm 0.05^{\mathrm{f}}$ \\
F6 & $11.29 \pm 0.12^{\mathrm{a}}$ & $59.53 \pm 0.97^{\mathrm{a}}$ \\
Standard & $>0.1 \mathrm{mg} / 1$ & \\
$F$ test & $* *$ & $* *$ \\
$\%$ CV & 25.82 & 2.87 \\
\hline
\end{tabular}

The values shown in this table were the mean

**Means with different letters indicate significant differences, LSD test $(P<0.05)($ F1-F6 were liquid organic fertilizer formula $1-6)$

found that all formula contained IAA (Table 4). The IAA in liquid organic fertilizers was significantly different $(P<0.05)$. After 30 days of fermentation, the IAA content values increased in all liquid organic fertilizers. According to Kamla's (2007) research on bio-extract fermentation, such bio-extracts might serve as a food source for 
microorganisms in the process of plant hormone synthesis. These plant hormones were then able to stimulate plant growth. Standard liquid organic fertilizer (National Bureau of Agricultural Commodity and Food Standards, Ministry of Agriculture and Cooperatives 2005) requires a content of more than $0.1 \mathrm{mg} / \mathrm{l}$ of IAA and our fertilizer had an IAA content greater than $0.1 \mathrm{mg} / \mathrm{l}$ which is the standard level of Thai fertilizers.

\section{Germination index}

Determining the quality and maturity liquid fertilizer is important. The presence of phytotoxicity substances in the product would render it unsafe for use. Immature fertilizer is often contaminated with intermediate compounds such as ammonia and organic acids that cause toxicity in the plant. These compounds inhibit germination of root length. Fertilizer maturity can be evaluated in many ways, such as by detection on $\mathrm{C} / \mathrm{N}$ ratio, $\mathrm{NH}_{4}{ }^{+} / \mathrm{NO}_{3}{ }^{-}$ratio humicfication, Cation Exchange capacity (CEC), and germination index (GI) (Yang, and Chang, 1998). However, GI is the only means to easily measure, through a simple process to yield fast and reliable results. This method aims to measure toxic (phytotoxic substance) in plants resulting from incomplete maturity of the fertilizer by extracting the organic matter in fertilizer with a melting texture, organic acid salt group, phenolic group and other toxins (Tiquia et al., 1996). If the fertilizer is toxic, these elements will have a direct effect on seed germination and plant root length (Wong et al. 2001). Under Thailand's standards for liquid organic fertilizer (National Bureau of Agricultural Commodity and Food Standards, Ministry of Agriculture and Cooperatives 2005), maturity is indicated by GI value which is greater than $80 \%$. According to CCQC (2001), a GI value higher than $90 \%$ indicates the phytotoxic-free property of the tested fertilizers which could then be safely applied for plant growth. The effect of liquid organic fertilizer on the seed germination of Green Cos Lettuce is presented in Fig. 3. The liquid organic fertilizer samples, such as non-diluted and those diluted with distilled water in the ratio 1:10, showed lower germination index values (data not shown), as high concentrations of fertilizer had negative effect on seed germination. The inhibitory effect of liquid fertilizer on germination and growth of young seedlings was probably due to the high EC and heavy metal content (Lwin et al. 2012), and other toxic compounds such as ammonia (Ells et al. 1991), ethylene oxide (Wong et al. 1983) and phenolic compounds. Liquid organic fertilizer obtained at 30 days of fermentation and diluted at 1:100 gave a germination index greater than $100 \%$ which indicated that diluted liquid fertilizer of all formulas were without phytotoxicity to seed germination. The value of germination index was found highest in F3 (147.9\%) and was significantly different $(P<0.05)$ compared to that of the control (Fig. 3). Our result yielded data similar to that of Malaviya and Sharma (2011), who worked on the impact of distillery effluent on seed germination of Brassica napus L. They found decreasing values of germination index when diluted samples of fertilizers were used. Ramana et al. (2002), studying the effects of distillery effluent on the germination of some vegetable seeds, showed similar results, and in their findings the germination index was lower when the concentration of effluent was higher.

\section{Growth of Green Cos Lettuce in the hydroponics cultivation}

In this experiment, liquid organic fertilizer contained only small amounts of total $\mathrm{N}$ and $\mathrm{P}$, which was lower than the Thai agricultural standard. However, it was a rich source of total $\mathrm{K}$ due to the substrates used in production. Moreover, the liquid organic fertilizer contained micro and supplement nutrients and also beneficial microorganisms such as plant growth-promoting rhizobacteria (PGPR) not found in chemical fertilizers. Most importantly, hormone IAA product was found in the liquid organic fertilizers. The IAA content was $59.53 \mathrm{mg} / \mathrm{l}$. This hormone was produced by microorganisms, with some found in the plant substrate. IAA stimulates the growth of root hairs and increases the root surface area. This
Fig. 3 Germination index of Green Cos Lettuce in different formula of liquid organic fertilizer. Different letters indicate significant difference values at $P<0.05$ by LSD $(15 \mathrm{D}-15$ days fermentation, $30 \mathrm{D}-30$ days fermentation, 1:100—ratio of liquid organic fertilizer: water, F1-F6 were liquid organic fertilizer formula $1-6$

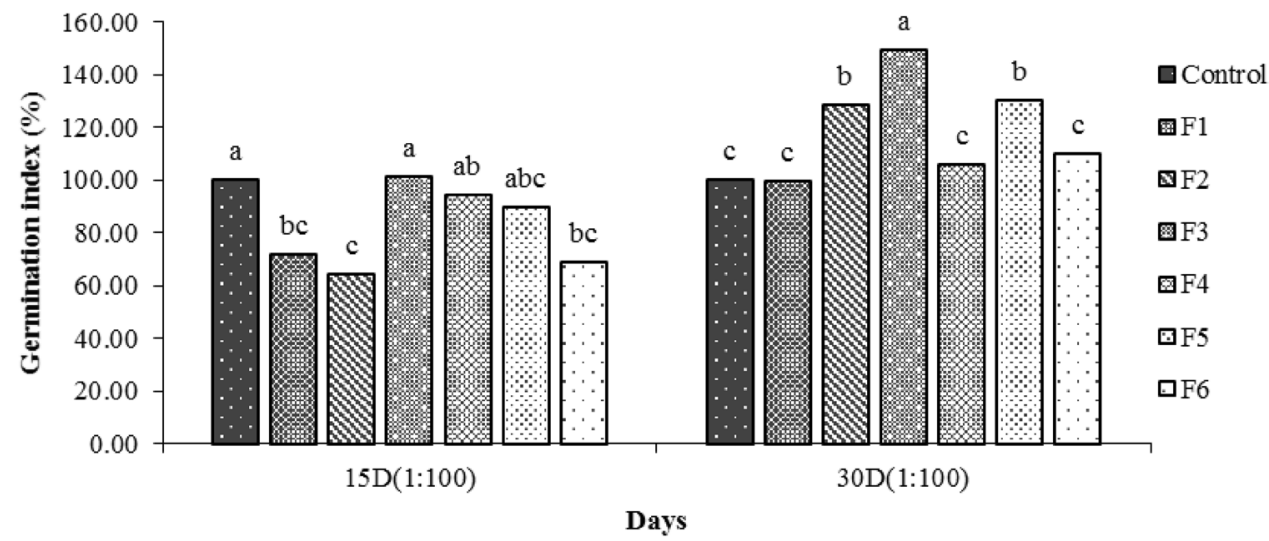


advantage was unique to the liquid organic fertilizer, as these nutrients are not found in chemical fertilizer. Increased root growth means that the plant can better absorb water and nutrients. The combination of chemical fertilizer and organic fertilizer indicated a possible decrease in the population of beneficial microorganisms in hydroponic systems (2006). These microorganisms (such PGPRs) have been used in
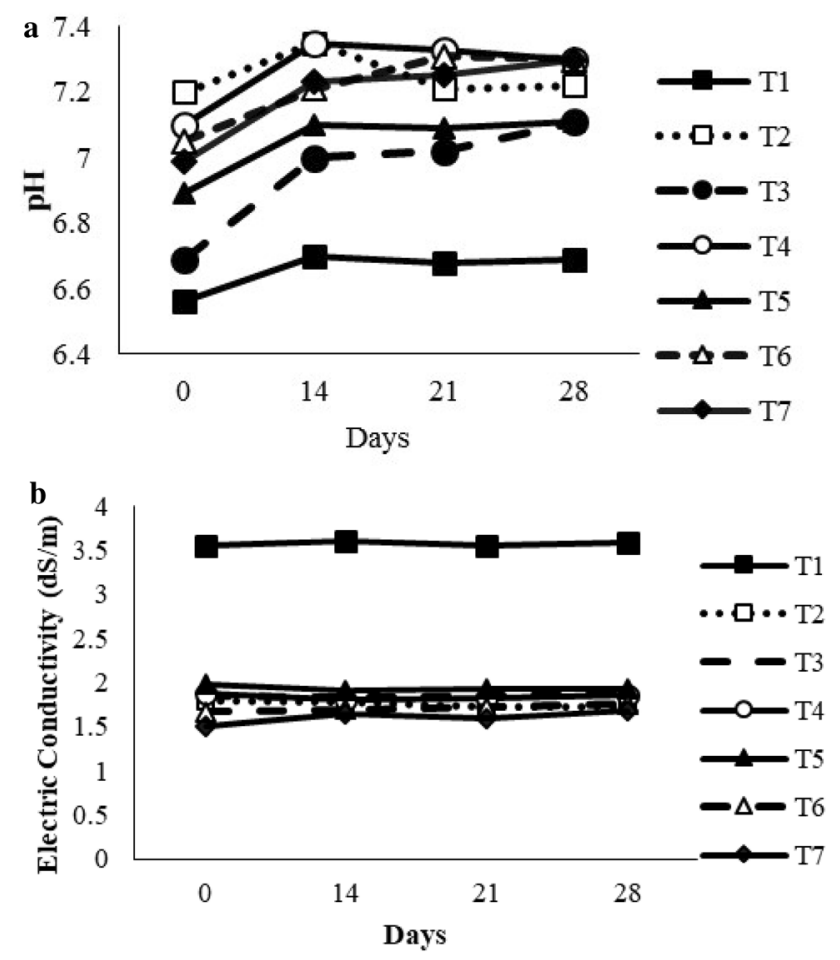

Fig. 4 pH (a) and EC (b) of hydroponic solutions containing different liquid organic fertilizers used to culture Green Cos Lettuce agriculture as biofertilizers, bio-control agents, and bioremediations. PGPR have been introduced into both soil and hydroponic systems with positive effects on plant quality and quantity (Kidoglu et al. 2009; Lee and Lee 2015). PGPR act through: $\mathrm{N}_{2}$ fixation, control of plant stress, extracting nutrients from soil, competition with pathogens, production of various kinds of plant hormones and biological controls, and promotion of plant growth (Bull et al. 1991; Freitas et al. 1993; Gaskins et al. 1985; Kloepper 1993; Lugtenberg and Kamilova 2009). The result from this work indicated that hydroponic systems that used liquid organic fertilizer were a suitable medium for observing interactions between rhizobacteria and roots. After the germination experiment, an experiment was carried out to confirm the effects of the liquid organic fertilizer on the growth of the vegetable. The optimum dilution ratio (1:100 ratio liquid organic fertilizer: water) for organic fertilizers, which was indicated by the above results, was used in this experiment. Hydroponic cultivation (NFT) was selected for growing the lettuce. The $\mathrm{pH}$ (Fig. 4a) and EC (Fig. 4b) values of diluted (1:200) liquid organic fertilizers (T2-T7) and diluted (1:200) liquid chemical fertilizer $\mathrm{AB}$ changed slightly from day 0 to day 28 of planting. The highest electrical conductivity was found in T1 (chemical fertilizer AB) (Fig. 4b). Chemical fertilizers $\mathrm{A}$ and $\mathrm{B}$ were fed to the plants as a control treatment. Effects of liquid organic fertilizers (T2-T7) and liquid chemical fertilizer AB (T1) on the growth of Green Cos Lettuce varied according to the treatments (Tables 5, 6, 7). After 14 days of cultivation (Table 5), T1 (chemical fertilizer AB) showed the greatest plant height $(11.60 \mathrm{~cm})$, leaf length $(10.33 \mathrm{~cm})$ and leaf width $(4.66 \mathrm{~cm})$. However, T6 (F5) gave the highest Green Cos Lettuce growth among the liquid organic fertilizer treatments. The highest growth parameters of lettuce

Table 5 Effect of liquid chemical fertilizer (T1) and six formulas of liquid organic fertilizers (T2-T7) on the Green Cos Lettuce at 14 DAT

\begin{tabular}{|c|c|c|c|c|c|c|c|}
\hline Treatments & $\begin{array}{l}\text { Number of } \\
\text { leaves }\end{array}$ & Root length (cm) & Plant height $(\mathrm{cm})$ & $\begin{array}{l}\text { Length of leaf } \\
(\mathrm{cm})\end{array}$ & $\begin{array}{l}\text { Width of leaf } \\
(\mathrm{cm} .)\end{array}$ & $\begin{array}{l}\text { Shoot fresh } \\
\text { weight }(g)\end{array}$ & $\begin{array}{l}\text { Shoot dry } \\
\text { weight } \\
\text { (g) }\end{array}$ \\
\hline $\mathrm{T} 1$ & 6.00 & $18.00^{\mathrm{c}}$ & $11.60^{\mathrm{a}}$ & $10.33^{\mathrm{a}}$ & $4.46^{\mathrm{a}}$ & $2.33^{\mathrm{b}}$ & $0.10^{\mathrm{b}}$ \\
\hline $\mathrm{T} 2(\mathrm{~F} 1)$ & 2.00 & $5.00^{\mathrm{f}}$ & $1.50^{\mathrm{g}}$ & $1.00^{\mathrm{f}}$ & $0.86^{\mathrm{e}}$ & $0.10^{\mathrm{e}}$ & $0.01^{\mathrm{f}}$ \\
\hline T3 (F2) & 4.00 & $4.30^{\mathrm{f}}$ & $5.00^{\mathrm{f}}$ & $1.22^{\mathrm{f}}$ & $0.84^{\mathrm{e}}$ & $0.23^{\mathrm{d}}$ & $0.01^{\mathrm{f}}$ \\
\hline $\mathrm{T} 4(\mathrm{~F} 3)$ & 5.00 & $20.73^{\mathrm{b}}$ & $8.20^{\mathrm{c}}$ & $6.80^{\mathrm{c}}$ & $3.30^{\mathrm{b}}$ & $1.04^{\mathrm{c}}$ & $0.07^{\mathrm{c}}$ \\
\hline T5 (F4) & 4.00 & $10.16^{\mathrm{d}}$ & $5.76^{\mathrm{d}}$ & $5.33^{\mathrm{d}}$ & $2.76^{\mathrm{c}}$ & $1.03^{\mathrm{c}}$ & $0.03^{\mathrm{d}}$ \\
\hline T6 (F5) & 6.00 & $24.03^{\mathrm{a}}$ & $11.06^{\mathrm{b}}$ & $9.80^{\mathrm{b}}$ & $4.36^{\mathrm{a}}$ & $2.42^{\mathrm{a}}$ & $0.15^{\mathrm{a}}$ \\
\hline T7 (F6) & 4.00 & $8.16 \mathrm{e}$ & $5.43^{\mathrm{e}}$ & $4.33^{\mathrm{e}}$ & $1.50^{\mathrm{d}}$ & $0.27^{\mathrm{d}}$ & $0.02^{\mathrm{e}}$ \\
\hline$F$ test & ns & $* *$ & $* *$ & $* *$ & $* *$ & $* *$ & $* *$ \\
\hline$\% \mathrm{CV}$ & 0.00 & 5.98 & 1.33 & 4.09 & 4.16 & 3.17 & 8.18 \\
\hline
\end{tabular}

The values shown in this table were the mean

$n s$ non-significant differences

**Means with different letters indicate significant differences, LSD test $(P<0.05)$, (T) were as follows: feed liquid chemical fertilizers A and B; (T1), feed liquid organic fertilizers F1-F6 were T2-T7, respectively 
Table 6 Effect of liquid chemical fertilizer (T1) and six formulas of liquid organic fertilizers (T2-T7) on the Green Cos Lettuce at 21 DAT

\begin{tabular}{|c|c|c|c|c|c|c|c|}
\hline Treatments & Number of leaves & Root length $(\mathrm{cm})$ & Plant height (cm) & $\begin{array}{l}\text { Length of } \\
\text { leaf }(\mathrm{cm})\end{array}$ & Width of leaf $(\mathrm{cm})$ & $\begin{array}{l}\text { Shoot fresh } \\
\text { weight }(\mathrm{g})\end{array}$ & $\begin{array}{l}\text { Shoot dry } \\
\text { weight } \\
\text { (g) }\end{array}$ \\
\hline T1. & 10.00 & $29.46^{\mathrm{bc}}$ & $16.66^{\mathrm{a}}$ & $7.76^{\mathrm{a}}$ & $18.73^{\mathrm{a}}$ & $19.72^{\mathrm{b}}$ & $1.26^{\mathrm{a}}$ \\
\hline $\mathrm{T} 2(\mathrm{~F} 1)$ & 3.00 & $9.33^{\mathrm{e}}$ & $9.00^{\mathrm{cd}}$ & $2.80^{\mathrm{g}}$ & $1.50^{\mathrm{e}}$ & $0.12^{\mathrm{e}}$ & $0.01^{\mathrm{e}}$ \\
\hline T3 (F2) & 6.00 & $24.00^{c}$ & $9.66^{\mathrm{c}}$ & $4.00^{\mathrm{d}}$ & $12.00^{\mathrm{c}}$ & $2.73^{\mathrm{d}}$ & $0.13^{\mathrm{d}}$ \\
\hline T4 (F3) & 9.00 & $37.66^{\mathrm{a}}$ & $17.33^{\mathrm{a}}$ & $7.00^{\mathrm{b}}$ & $18.83^{\mathrm{a}}$ & $21.65^{\mathrm{a}}$ & $0.93^{\mathrm{b}}$ \\
\hline T5 (F4) & 5.00 & $22.66^{\mathrm{c}}$ & $7.50^{\mathrm{e}}$ & $3.50^{\mathrm{e}}$ & $9.26^{\mathrm{d}}$ & $1.99^{\mathrm{d}}$ & $0.11^{\text {bd }}$ \\
\hline T6 (F5) & 9.00 & $31.33^{\mathrm{b}}$ & $13.50^{\mathrm{b}}$ & $5.60^{\mathrm{c}}$ & $14.53^{\mathrm{b}}$ & $11.71^{\mathrm{c}}$ & $0.70^{\mathrm{c}}$ \\
\hline T7 (F6) & 5.00 & $19.90^{\mathrm{d}}$ & $8.23^{\mathrm{d}}$ & $3.00^{\mathrm{f}}$ & $9.83^{\mathrm{d}}$ & $2.103^{\mathrm{d}}$ & $0.09^{\mathrm{d}}$ \\
\hline$F$ test & $* *$ & $* *$ & $* *$ & $* *$ & $* *$ & $* *$ & $* *$ \\
\hline$\% \mathrm{CV}$ & 0.00 & 4.85 & 4.43 & 0.45 & 4.53 & 5.51 & 7.92 \\
\hline
\end{tabular}

The values shown in this table were the mean

**Means with different letters indicate significant differences, LSD test $(P<0.05)$

(T) were as follows: feed liquid chemical fertilizers A and B (T1), feed liquid organic fertilizers F1-F6 were T2-T7, respectively

Table 7 Effect of liquid chemical fertilizer (T1) and six formulas of liquid organic fertilizers (T2-T7) on the Green Cos Lettuce at 28 DAT

\begin{tabular}{|c|c|c|c|c|c|c|c|}
\hline Treatments & Number of leaves & Root length $(\mathrm{cm})$ & Plant height $(\mathrm{cm})$ & $\begin{array}{l}\text { Length of } \\
\text { leaf }(\mathrm{cm})\end{array}$ & $\begin{array}{l}\text { Width of leaf } \\
(\mathrm{cm})\end{array}$ & $\begin{array}{l}\text { Shoot fresh } \\
\text { weight }(\mathrm{g})\end{array}$ & $\begin{array}{l}\text { Shoot dry } \\
\text { weight } \\
\text { (g) }\end{array}$ \\
\hline $\mathrm{T} 1$. & $15.33^{\mathrm{b}}$ & $10.00^{\mathrm{f}}$ & $23.26^{\mathrm{a}}$ & $21.33^{\mathrm{a}}$ & $9.93^{\mathrm{a}}$ & $88.28^{\mathrm{a}}$ & $3.43^{\mathrm{a}}$ \\
\hline $\mathrm{T} 2(\mathrm{~F} 1)$ & $3.00^{f}$ & $11.33^{\mathrm{e}}$ & $1.83^{\mathrm{e}}$ & $1.35^{\mathrm{f}}$ & $2.50^{\mathrm{f}}$ & $0.12^{\mathrm{e}}$ & $0.02^{f}$ \\
\hline T3 (F2) & $11.00^{\mathrm{d}}$ & $21.83^{\mathrm{c}}$ & $14.13^{\mathrm{b}}$ & $12.43^{\mathrm{c}}$ & $4.26^{\mathrm{d}}$ & $7.92^{\mathrm{d}}$ & $0.38^{\mathrm{d}}$ \\
\hline T4 (F3) & $18.00^{\mathrm{a}}$ & $33.66^{\mathrm{a}}$ & $24.00^{\mathrm{a}}$ & $19.33^{\mathrm{b}}$ & $8.26^{\mathrm{b}}$ & $69.32^{\mathrm{b}}$ & $2.43^{\mathrm{b}}$ \\
\hline T5 (F4) & $5.00^{\mathrm{e}}$ & $11.26^{\mathrm{e}}$ & $8.50^{\mathrm{d}}$ & $7.50^{\mathrm{e}}$ & $3.50^{\mathrm{e}}$ & $1.67^{\mathrm{e}}$ & $0.15^{\mathrm{ef}}$ \\
\hline T6 (F5) & $12.00^{\mathrm{c}}$ & $27.10^{\mathrm{b}}$ & $14.50^{\mathrm{b}}$ & $12.36^{\mathrm{c}}$ & $5.16^{\mathrm{c}}$ & $13.88^{\mathrm{c}}$ & $1.03^{c}$ \\
\hline T7 (F6) & $11.00^{\mathrm{d}}$ & $15.66^{\mathrm{d}}$ & $12.33^{\mathrm{c}}$ & $10.10^{\mathrm{d}}$ & $4.00^{\mathrm{d}}$ & $7.32^{\mathrm{d}}$ & $0.32^{\mathrm{df}}$ \\
\hline$F$ test & $* *$ & $* *$ & $* *$ & $* *$ & $* *$ & $* *$ & $* *$ \\
\hline$\% \mathrm{CV}$ & 4.06 & 3.46 & 3.50 & 2.88 & 3.61 & 9.63 & 8.98 \\
\hline
\end{tabular}

The values shown in this table were the mean

**Means with different letters indicate significant differences, LSD test $(P<0.05)$; $(\mathrm{T})$ were as follows: feed liquid chemical fertilizers A and B (T1), feed liquid organic fertilizers F1-F6 were T2-T7, respectively

grown in T6 (F5) were root length $(24.03 \mathrm{~cm})$, leaf width $(4.36 \mathrm{~cm})$, shoot fresh weight $(2.42 \mathrm{~g})$ and shoot dry weight $(0.15 \mathrm{~g})$ which were significantly different $(P<0.01)$ from those of other treatments. However, after 21 days of cultivation, T4 (F3) gave the highest growth parameters, including root length $(37.66 \mathrm{~cm})$, plant height $(17.33 \mathrm{~cm})$, leaf width $(18.83 \mathrm{~cm})$ and shoot fresh weight $(21.65 \mathrm{~g})$ (Table 6). After 28 days of cultivation, T4 (F3) still gave the highest growth among the liquid organic fertilizers. Plants cultured in T4 (F3) had a significantly higher number of leaves and greater root length than those grown with $\mathrm{T} 1$, whereas all other growth parameters were similar to or lower than those in $\mathrm{T} 1$ (Table 7). The liquid organic fertilizer was without pathogen, indicated by a negative result on detecting $E$. coli. The study of Shinohara et al. (2011) presented a novel and practical hydroponic culture method using microorganisms to degrade organic substrate and utilizing fish-based soluble matter in the hydroponic solution which has been developed as an organic fertilizer. In addition, this research found that the lettuce seedlings grew well when the microbial culture solution was used. Nelson (2013) compared organic and inorganic fertilizers for hydroponic lettuce production. In this study, it was found that liquid organic fertilizer formula 3 and 5 showed no significant difference in all growth parameters measured when compared to the results using chemical fertilizer as a treatment (Fig. 5). Nitrate content was determined in the liquid organic fertilizer formula 3 which was sampled at 15 and 30 days of fermentation. It was found that the nitrate contents were 19.07 and $19.95 \mathrm{mg} / \mathrm{l}$, lower amounts than in the chemical fertilizer AB (type A 32,240 and type B $27,115 \mathrm{mg} / \mathrm{l}$, respectively). The inorganic fertilizer was found to contain more nitrates. However, it was discovered 


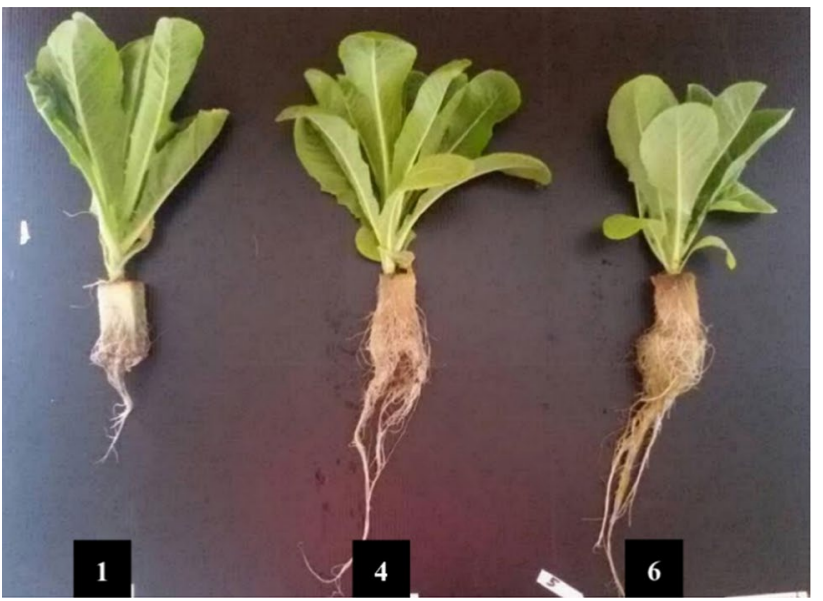

Fig. 5 Effect of liquid chemical fertilizer and liquid organic fertilizer on the Green Cos Lettuce. $1=\mathrm{T} 1$ (liquid chemical fertilizers A and $\mathrm{B}$ ), $4=\mathrm{T} 4$ (liquid organic fertilizer $\mathrm{F} 3$ ) and $6=\mathrm{T} 6$ (liquid organic fertilizer F5)

that the amount of nitrogen must be in a balanced form. In this research, toxins and heavy metals in liquid organic fertilizers of all formula were below the limits mandated by Thai Agricultural standards. The research of Mavrogianopoulos et al. (2002) used wastewater for hydroponic cultivation and examined the efficiency of giant reed (Arundo donax L.) as a source of biomass production and bio-based filtering device for sewage effluents. Giant reed populations showed a positive response to wastewater applications, in terms of growth and biomass production and gave no visual sign of detrimental or toxic effect. It can be concluded that organic hydroponics based on this method is a practical solution using organic sources as a fertilizer (Shinohara et al. 2011).

\section{Chlorophyll content}

Chlorophyll is essential to photosynthesis and plant leaves with high chlorophyll content will gain energy and produce food more efficiently (National Bureau of Agricultural Commodity and Food Standards, Ministry of Agriculture and Cooperatives 2005). The main nutrients required are nitrogen, phosphorus, and potassium. Nitrogen is an important nutrient for chlorophyll production (Tancho 2013). Leaf chlorophyll content is related to the amount of nitrogen, which is a component of the chlorophyll structure. Cabrera (1998) found that the nitrogen content of a leaf was related to its color. Chlorophyll is the main pigment in plants and a greener leaf indicates more pigment and, therefore, more nitrogen. According to Lesing and Aungoolprasert (2016), organic fertilizer was the source of nitrogen, and similarly it presented higher chlorophyll content in kale leaves. Previous research showed that the pigment in green cos lettuce contained the chlorophyll A, B and total chlorophyll. In general, leaf chlorophyll content is affected by environmental conditions such as light volume and salinity changes. According to Romero-Aranda et al. (2001), as the value of the EC of the solution increased, the amount of chlorophyll within the leaves of the tomato also increased. The effects of liquid chemical fertilizer and liquid organic fertilizer on the chlorophyll contents of Green Cos Lettuce are presented in Table 8 . The variation in chlorophyll content was found to be significantly different in all treatments. The highest chlorophyll a, chlorophyll b and total chlorophyll were found in T6 which were similar to T1. The lowest chlorophyll contents were found in $\mathrm{T} 2$.
Table 8 Effect of various treatments on chlorophyll content of Green Cos Lettuce

\begin{tabular}{|c|c|c|c|c|c|c|c|c|c|}
\hline \multirow[t]{3}{*}{ Treatments } & \multicolumn{9}{|c|}{ Chlorophyll content (mg/0.1 g of FW) } \\
\hline & \multicolumn{3}{|c|}{ Chlorophyll A } & \multicolumn{3}{|c|}{ Chlorophyll B } & \multicolumn{3}{|c|}{ Total Chlorophyll } \\
\hline & 14 day & 21 day & 28 day & 14 day & 21 day & 28 day & 14 day & 21 day & 28 day \\
\hline 1 & $1.12^{\mathrm{bc}}$ & $1.42^{\mathrm{b}}$ & $1.64^{\mathrm{a}}$ & $0.40^{\mathrm{b}}$ & $0.57^{\mathrm{ab}}$ & $0.63^{\mathrm{a}}$ & $1.53^{\mathrm{b}}$ & $2.00^{\mathrm{a}}$ & $2.28^{\mathrm{a}}$ \\
\hline 2 & $0.42^{\mathrm{e}}$ & $0.18^{\mathrm{d}}$ & $0.28^{\mathrm{e}}$ & $0.18^{\mathrm{c}}$ & $0.18^{\mathrm{c}}$ & $0.47^{\mathrm{ab}}$ & $0.61^{\mathrm{d}}$ & $0.36^{\mathrm{c}}$ & $0.76^{\mathrm{cd}}$ \\
\hline 3 & $0.83^{\mathrm{cd}}$ & $1.09^{\mathrm{c}}$ & $0.77^{\mathrm{d}}$ & $0.29^{\mathrm{bc}}$ & $0.30^{\mathrm{bc}}$ & $0.26^{\mathrm{b}}$ & $1.13^{\mathrm{c}}$ & $1.40^{\mathrm{b}}$ & $1.03^{\mathrm{c}}$ \\
\hline 4 & $1.26^{\mathrm{b}}$ & $1.07^{\mathrm{c}}$ & $1.26^{\mathrm{b}}$ & $0.26^{\mathrm{bc}}$ & $0.49^{\mathrm{ab}}$ & $0.46^{\mathrm{ab}}$ & $1.52^{\mathrm{b}}$ & $1.56^{\mathrm{b}}$ & $1.73^{\mathrm{b}}$ \\
\hline 5 & $0.93^{\mathrm{cd}}$ & $1.42^{\mathrm{b}}$ & $0.37^{\mathrm{e}}$ & $0.27^{\mathrm{bc}}$ & $0.67^{\mathrm{a}}$ & $0.34^{\mathrm{b}}$ & $1.21^{\mathrm{bc}}$ & $2.10^{\mathrm{a}}$ & $0.72^{\mathrm{d}}$ \\
\hline 6 & $1.65^{\mathrm{a}}$ & $1.60^{\mathrm{a}}$ & $1.55^{\mathrm{a}}$ & $0.84^{\mathrm{a}}$ & $0.60^{\mathrm{a}}$ & $0.59^{\mathrm{a}}$ & $2.49^{\mathrm{a}}$ & $2.20^{\mathrm{a}}$ & $2.15^{\mathrm{a}}$ \\
\hline 7 & $0.67^{\mathrm{de}}$ & $1.13^{\mathrm{c}}$ & $1.14^{\mathrm{c}}$ & $0.23^{b c}$ & $0.44^{\mathrm{abc}}$ & $0.34^{\mathrm{b}}$ & $0.90^{\mathrm{cd}}$ & $1.57^{\mathrm{b}}$ & $1.48^{b}$ \\
\hline$F$ test & $* *$ & $* *$ & $* *$ & $* *$ & $*$ & $*$ & $* *$ & $* *$ & $* *$ \\
\hline$\% \mathrm{CV}$ & 18.58 & 5.55 & 6.40 & 33.84 & 33.86 & 28.14 & 13.92 & 11.46 & 11.44 \\
\hline
\end{tabular}

The values shown in this table were the mean

**Means with different letters indicate significant differences, LSD test $(P<0.05)$; $(\mathrm{T})$ were as follows: feed liquid chemical fertilizers A and B (T1), feed liquid organic fertilizers F1-F6 were T2-T7, respectively 


\section{Conclusion}

In this study, organic residues from agro-industry factories, distillery slop and molasses, and sugarcane leaves were used as substrates for the production of liquid organic fertilizers after 30 days fermentation. Six formulas (F1-F6) of liquid organic fertilizers were produced with varying ratios of those three main organic substrates. Liquid organic fertilizer had an IAA content greater than $0.1 \mathrm{mg} / \mathrm{l}$ which is the standard level of Thai fertilizer. The liquid organic fertilizers produced were used to grow Green Cos Lettuce in a hydroponic system. The most important step for organic fertilizer production is checking fertilizer maturity before commercial distribution. A seed germination test was used to detect phytotoxicity substances contained within immature fertilizer. The germination index of the lettuce seeds was greater than $100 \%$, which indicated that all formulas of liquid organic fertilizers were free from the phytotoxicity substances which cause problems for seed germination. The effects of liquid organic fertilizer on the growth of Green Cos Lettuce in hydroponic culture using nutrient film technique (NFT) system showed that the plants cultured with F3 (distillery slop: sugarcane leaves 1:0.1:0.25 v:w:v) and F5 (distillery slop: sugarcane leaves 1:0.25:0.25 v:w:v) had the highest growth parameters. These included the highest chlorophyll a, chlorophyll b and total chlorophyll content, levels similar to those found with chemical fertilizers. This indicated that organic liquid fertilizers Formulas 3 and 5 had effects comparable to chemical fertilizers on growth promotion of Green Cos Lettuce. Moreover, our products are environmental friendly as they utilize and effectively recycle waste products, while serving as a rich nutrient source for the plant.

Acknowledgements The author would like to thank Research and Researchers for Industries-RRI, Master degree level 2014 and KSL Green Innovation Public Company Limited (Khon Kaen, Thailand) factory for supporting the budget and the location for hydroponic cultivation. We also thank to Department of Microbiology, Faculty of Science, Khon Kaen University, and Thailand and Microbial fertilizer Lab group for assisting us in the experiments. Finally, we would like to thank Assoc. Prof. Dr. Piyada Theerakulpisut for suggestions on data writing. Thanks to Dr. Andrew john Hunt for English proofreading.

Open Access This article is distributed under the terms of the Creative Commons Attribution 4.0 International License (http://creativeco mmons.org/licenses/by/4.0/), which permits unrestricted use, distribution, and reproduction in any medium, provided you give appropriate credit to the original author(s) and the source, provide a link to the Creative Commons license, and indicate if changes were made.

\section{References}

Alexander M (1977) Introduction to soil microbiology, 2nd edn. Wiley, New York

Anjana SU, Iqbal M (2007) Nitrate accumulation in plants, factors affecting the process and human health implications. A review. Agron Sustain Dev 27(1):45-57. https://doi.org/10.1051/agro:2006021
Arnon DI (1949) Copper enzymes in isolated chloroplasts. Polyphenoloxidase in Beta vulgaris. Plant Physiol 24:1-15. https://doi. org/10.1104/pp.24.1.1

Atlas RM (2004) Handbook of microbiological media. Florida, Boca Raton

Barton CJ (1948) Photometric analysis of phosphate rock. Anal Chem 20(11):1068-1073

Black CA (1965) Method of soil analysis part 2. Agronomy 9. American Society of Agronomy, Wiscosin

Bull CT, Weller DM, Thomashow LS (1991) Relationship between root colonization and supression of Gaeumannomyces graminis var. tritici by Pseudomonas fluorescens strain 2-79. Phytopathology 81:954-959. https://doi.org/10.1094/Phyto-81-954

Cabrera RI (1998) Evaluating yield and quality of roses with respect to nitrogen fertilization and leaf nitrogen status. In: XXV international horticultural congress, part 1: culture techniques with special emphasis on environmental implications, vol 511, pp 133-142

CCQC (California Compost Quality Council) (2001) Compost Maturity index California Compost Quality Council, Nevada City, California. Pollut Ser A Ecol Biol 30(2):109-123. http://compo sting council.org/wp/wp-content/uploads/2014/02/2-CCQCM aturity-Index.pdf. Accessed 1 Sept 2018

Ells JE, MeSay AE, Workman SM (1991) Toxic effects of manure, alfalfa, and ammonia on emergence and growth of cucumber seedlings. HortScience 26(4):380-383

Freitas JR, Gupta VVSR, Germida JJ (1993) Influence of Pseudomonas syringae $\mathrm{R} 25$ and $P$. putida $\mathrm{R} 105$ on the growth and $\mathrm{N}_{2}$ fixation (acetylene reduction activity) of pea ( $P$. sativum L.) and field bean (Phaseolus vulgaris L.). Biol Fertil Soils 16:215-220. https://doi.org/10.1007/BF00361411

Gaskins MH, Albrecht SL, Hubbell DH (1985) Rhizosphere bacteria and their use to increase plant productivity: a review. Agric Ecosyst Environ 12:99-116. https://doi.org/10.1016/01678809(85)90071-4

Gent MP (2003) Solution electrical conductivity and ratio of nitrate to other nutrients affect accumulation of nitrate in hydroponic lettuce. HortScience 38(2):222-227

Glick BR (2003) Three newly isolated plant growth-promoting bacilli facilitate the seedling growth of canola, Brassica campestris. Plant Physiol Biochem 41:277-281

Hadad R, Anderson GR (2004) Analysis of organic fertilizers for use in vegetable transplant production. IOP Publishing Physics Web. http://www.uky.edu/hort/sites/www.uky.edu.hort/files/ documents/orgfert1.pdf. Accessed 24 June 2016

Hesse PR, Hesse PR (1971) Textbook of soil chemical analysis. William Clowes and Son, London

Hu X, Chen J, Guo J (2006) Two phosphate- and potassium-solubilizing bacteria isolated from Tianmu Mountain, Zhejiang, China. World J Microbiol Biotechnol 22:983-990. https://doi. org/10.1007/s11274-006-9144-2

Ikemoto Y, Teraguchi M, Kogayashi Y (2002) Plasma level of nitrate in congenital heart disease: comparison with healthy children. Pediatr Cardiol 23:132-136. https://doi.org/10.1007/s0024 6-001-0036-9

Ishiwata H, Yamada T, Yoshiike N, Nishijima M, Kawamoto A, Uyama Y (2002) Daily in take of food additives in Japan in five age groups estimated by the market basket method. Eur Food Res Technol 215:367-374. https://doi.org/10.1007/s00217-002-0577-z

Jones JB Jr (2016) Hydroponics: a practical guide for the soilless grower. CRC Press Library of Congress, Boca Raton

Kamla N (2007) Roles of fermented bio-extracts on soil microbial processes and crop growth. IOP Publishing KKUWeb http://lib18 .kku.ac.th/dcms/files//21134/Chapter2.pdf. Accessed 10 Mar 2017

Kıdoglu F, Gül A, Tüzel Y, Özaktan H (2009) Yield enhancement of hydroponically grown tomatoes by rhizobacteria. Acta Hortic 807:475-480. https://doi.org/10.17660/ActaHortic.2009.807.68 
Kjeldahl J (1883) Neue Methode zur Bestimmung des Stickstoffs in organischen Körpern. Z Anal Chem 22:366-382. https://doi. org/10.1007/BF01338151

Kloepper JW (1993) Plant-growth promoting rhizobacteria as biological control agents. In: Metting FB (ed) Soil microbial ecology applications in agricultural and environmental management. Marcel Dekker, New York

Leblanc H, Cerrato ME, Miranda A, Valle G (2007) Determinación de la calidad de abonos orgánicos a través de bioensayos. Tierra Trop 3(1):97-107

Lee S, Lee J (2015) Beneficial bacteria and fungi in hydroponic systems: types and characteristics of Hydroponic food production methods. Sci Hortic 195:206-215. https://doi.org/10.1016/j.scien ta.2015.09.011

Lesing S, Aungoolprasert O (2016) Efficacy of high quality organic fertilizer on growth and yield of Chinese kale. J Sci Technol 24(2):320-332

Lugtenberg B, Kamilova F (2009) Plant-growth-promoting rhizobacteria. Annu Rev Microbiol 63(1):541-556

Lwin KM, Myint MM, Tar T, Aung WZM (2012) Isolation of plant hormone (indole-3-acetic acid-IAA) producing rhizobacteria and study on their effects on maize seedling. Eng J 16(5):137-144

Malaviya P, Sharma A (2011) Impact of distillery on germination behavior of Brassica napus L. J Environ Biol 32(1):91-94

Sardare MD, Admane SV (2013) A review on plant without soilhydroponics. Int J Res Eng Technol 2(3):299-304. https://doi. org/10.15623/ijret.2013.0203013

Mavrogianopoulos G, Vogli V, Kyritsis S (2002) Use of wastewater as a nutrient solution in a closed gravel hydroponic culture of giant reed (Arundo donax). Bioresour Technol 82(2):103-107. https:// doi.org/10.1016/S0960-8524(01)00180-8

Moonrat W (2010) Effciency of fermented bioextract from fish in stillage on the growth of Amaranthus tricolor, Brassica campestris var. chinensis and Ipomoea aquatica var. reptans. IOP Publishing NewtdcWeb. http://newtdc.thailis.or.th/docview.aspx?tdcid $=263570$. Accessed 8 Jan 2017

Nasir AM, Khalid S, Anwar C, Arslan MJ, Sultan Akhtar M (2012) Evaluation on bio-fertilizer application to ameliorate the environment and crop production. Pak J Agric Sci 49(4):527-531

National Bureau of Agricultural Commodity and Food Standards, Ministry of Agriculture and Cooperatives (2005) Thai Agricultural Standard TAS 9503: Compost (Royal Gazette 122, Section 114D). Bangkok, Thailand

Nelson J (2013) Using organic fertilizers for hydroponic lettuce production. IOP Publishing KrexWeb http://krex.kstate.edu/dspace/ bitstream/handle/2097/15574/JasonNelson2013.pdf?sequence $=5$. Accessed 10 June 2017

Ortíz-Castro R, Contreras-Cornejo HA, Macías-Rodríguez L, LópezBucio J (2009) The role of microbial signals in plant growth and development. Plant Signal Behav 4(8):701-712

Patten C, Glick B (1996) Bacterial biosynthesis of indole-3-acetic acid. Can J Microbiol 42:207-220

Patten C, Glick B (2002) Role of Pseudomonas putida indoleacetic acid in development of the host plant root system. Appl Environ Microbiol 68:3795-3801

Pizzeghello D, Nicolini G, Nardi S (2001) Hormone-like activity of humic substances in Fagus sylvaticae forest. New Phytol 151:647-657

Ramana S, Biswas AK, Singh AB, Yadava RB (2002) Effect of distillery effluent on seed germination in somevegetable crops. Bioresour Technol 20:5-8. https://doi.org/10.1016/S0960 $-8524(01) 00184-5$

Ratneetoo B (2012) Organic fertilizer improves deteriorated soil. Princess Naradhiwas Univ J 4(2):115-127

Romero-Aranda R, Soria T, Cuartero T (2001) Tomato plant-water uptake and plant-water relationships under saline growth conditions. Plant Sci 160:265-272
Saelee S (2004) Characterization and assessment of commercially available liquid biofertilizers. IOP Publishing KKUWeb. http:// lib18.kku.ac.th/dcms/files//02508/Abstract.pdf. Accessed 22 May 2017

Sangla L, Suppadit T (2005) The impacts of sugarcane leaf burning and solving methods. Thai J Environ Manag Nida Thail 2:85-102

Saouy M (2002) Effective storage time of bioextracts and their effects on some soil properties. IOP Publishing KKUWeb. http://www. cab.kps.ku.ac.th/db_cab/thisis/reports/01-06-09-000011.pdf. Accessed 22 May 2017

Sarwar M, Arshad M, Martens DA, Frankenberger WT (1992) Tryptophan-dependent biosynthesis of auxins in soil. Plant Soil 147(2):207-215

Satisha GC, Devarajan L (2007) Effect of amendments on windows composting of sugar industry pressmud. Waste Manag 27:1083-1091

Savvas D (2002) Nutrient solution recycling. In: Savvas D, Passam HC (eds) Hydroponic production of vegetables and ornamentals. Embryo Publications, Athens, pp 299-343

Shinohara M, Aoyama C, Fujiwara K, Watanabe A, Ohmori H, Uehara Y, Takano M (2011) Microbial mineralization of organic nitrogen into nitrate to allow the use of organic fertilizer in hydroponics. Soil Sci Plant Nutr 57(2):190-203. https://doi.org/10.1080/00380 768.2011.554223

Surange S, Wollum AG, Kumar N, Nautiyal CS (1997) Characterization of Rhizobium from root nodules of leguminous trees growing in alkaline soils. Can J Microbiol 43:891-894. https://doi. org/10.1139/m97-130

Sureshkumar R, Mohideen ST, Nethaji N (2013) Heat transfer characteristics of nanofluids in heat pipes: a review. Renew Sustain Energy Rev 20:397-410

Tancho A (2013) Natural agriculture applied concepts in Thailand in 2013. National Science and Technology Development Agency, Bangkok

Tiquia SM, Tam NFY, Hodgkiss IJ (1996) Effects of composting on phytotoxicity of spent pig-manure sawdust litter. Environ Pollut 93(3):249-256

Wiparwin A (2006) The effect of compost and liquid manure on the yield of Chinese kale (Brassica oleracea var. altoglabra). IOP Publishing MJUWeb. http://webpac.library.mju.ac.th:8080/mm/ fulltext/thesis/2550/Aphirak_Wiparwin/\%E0\%B8\%AD\%E0\%B $8 \% \mathrm{~A} 0 \% \mathrm{E} 0 \% \mathrm{~B} 8 \% \mathrm{~B} 4 \% \mathrm{E} 0 \% \mathrm{~B} 8 \% \mathrm{~A} 3 \% \mathrm{E} 0 \% \mathrm{~B} 8 \% \mathrm{~B} 1 \% \mathrm{E} 0 \% \mathrm{~B} 8 \% 81$ \%Е0\%B8\%A9\%Е0\%B9\%8C\%20\%20\%Е0\%B8\%A7\%Е0\%B8\% B4\%Е0\%B8\%A0\%Е0\%B8\%B2\%Е0\%B8\%A7\%Е0\%B8\%B4\%Е 0\%B8\%99.pdf. Accessed 1 Sept 2018

Wong MH, Cheung YH, Cheung CL (1983) The effects of ammonia and ethylene oxide in animal manure and sewage sludge on the seed germination and root elongation of Brassica parachinensis. Environ Environ Pollut Ser A Ecol Biol 30(2):109-123

Wong JWC, Mak KF, Chan NW, Lam A, Fang M, Zhou LX, Liao XD (2001) Co-composting of soybean residues and leaves in Hong Kong. Biores Technol 76(2):99-106

Yang SS, Chang HL (1998) Effect of environmental conditions on methane production and emission from paddy soil. Agric Ecosyst Environ 69(1):69-80

Yusran FH (2008) Existing versus added organic matter in relation to phosphorus availability on lateritic soils. J Trop Soils 13:23-34

Zucconi F, Monaco A, Debertoldi M (1981) Biological evaluation of compost maturity. Biocycle 22(4):27-29

Publisher's Note Springer Nature remains neutral with regard to jurisdictional claims in published maps and institutional affiliations. 